\title{
Performance of Native Grasses and Cultivated Legumes and Grasses on Disturbances in the Eastern Slopes of the Rockies
}

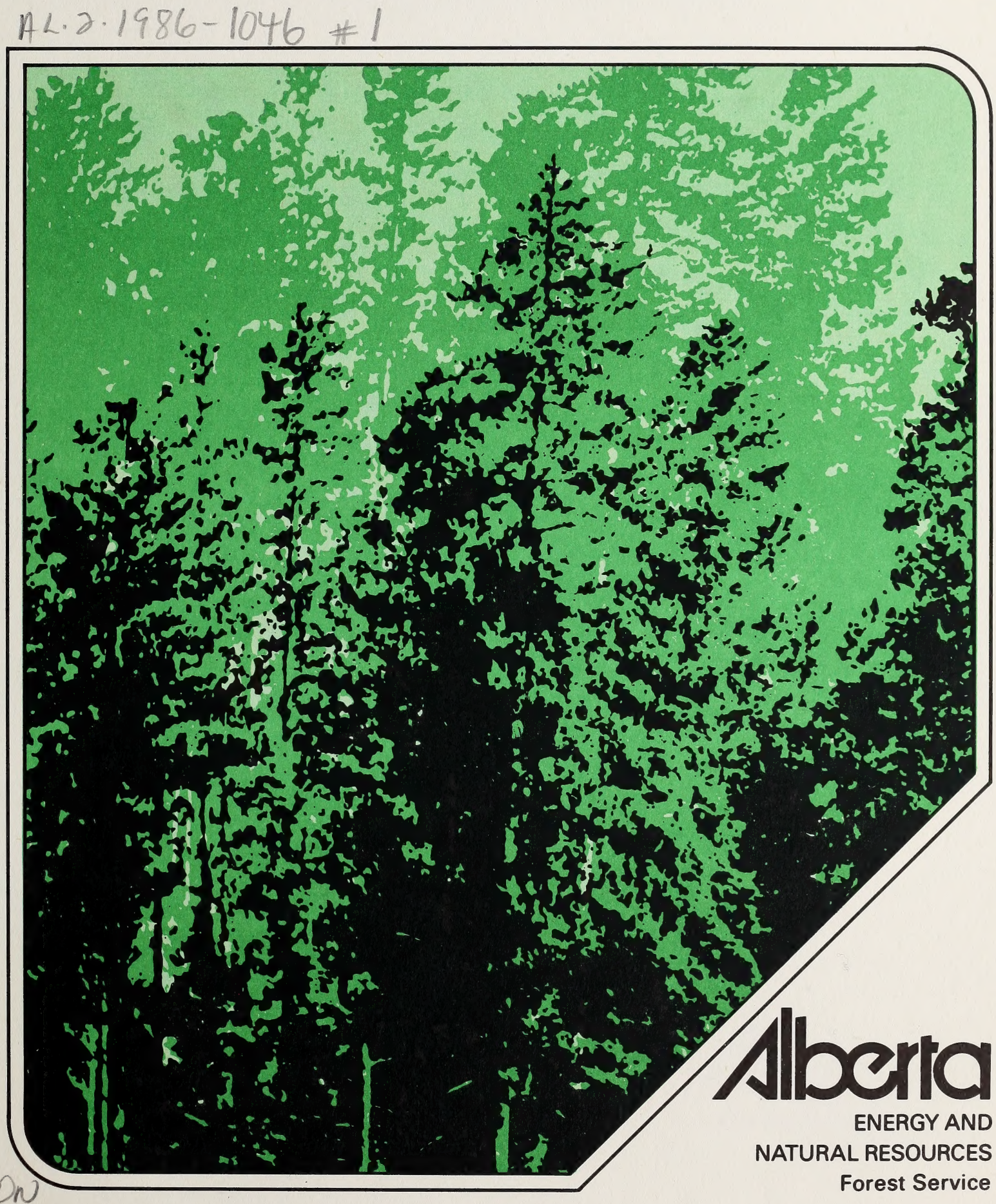

Forest Service 



\section{PERFORMANCE OF NATIVE GRASSES}

AND CULTIVATED LEGUMES AND

GRASSES ON DISTURBANCES

IN THE EASTERN SLOPES

OF THE ROCKIES

S.K. Takyi and R.M. Islam 
ENR Technical Report Number: T/68

FOR ADDITIONAL COPIES OF THIS PAPER, CONTACT:

Alberta Energy and Natural Resources, Information Centre, Main Floor, Bramalea Building, 9920 - 108 Street, Edmonton, Alberta, Canada T5K $2 \mathrm{M} 4$

Phone: 403-427-3590 
That

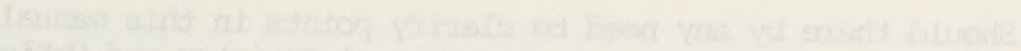

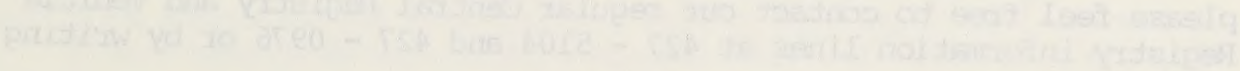

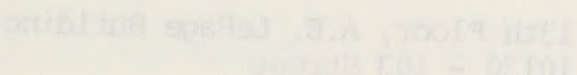

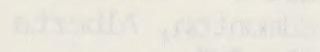

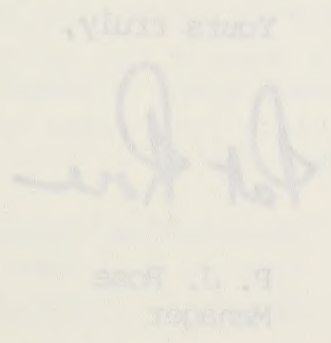


will proceed after proclamation so that for some time search services will continue at the existing level.

Should there by any need to clarify points in this manual, please feel free to contact our regular Central Registry and Vehicle Registry information lines at $427-5104$ and $427-0976$ or by writing the Branch at:

13th Floor, A.E. LePage Building 10130 - 103 Street Edmonton, Alberta T5J 3N9.

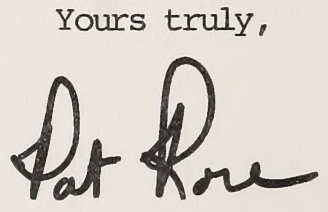

P. J. Rose Manager 
Digitized by the Internet Archive in 2016 
May 3, 1984

\section{Dear Users:}

In order to accomodate the provisions of the Chattel Security Registries Act, S.A. 1983, C. C 7.1, we will be introducing a new computerized system for both the Central and Vehicle Registries of the Personal Property Registration Branch. The result of computerization is that we will be able to efficiently handle our ever increasing volume of registrations, as well as, to continue to provide our clients with accurate and timely searches.

Upon proclamation of the Chattel Security Registries Act on August 1, 1984 there will be new requirements for documents submitted for registration. The prime change will be the requirement of a Financial Interest Statement or an Amending Financial Interest Statement to accompany documents for registration. The attached Registration Guide details what forms will be required and how the forms are to be completed. The forms themselves will be used for data entry to the computer system and will be very similar to the type of form submitted in notice filing under a Personal Property Security Act.

The forms are now available and may be obtained by writing to the address shown on page 6 of the Guide. The forms are free of charge and fees for the services of the registries will continue at their current rate. In ordering, please remember to specify the quantity of each type of form required, taking into consideration the volumes of registrations you might have. We request that you place your order early as it will take some time to respond to each order.

While we were developing our computerized system we were also converting Central Registry records. Thus we will soon be able to provide computerized searches in that registry. Vehicle Registry conversion 


\title{
PERFORMANCE OF NATIVE GRASSES AND CULTIVATED \\ LEGUMES AND GRASSES ON DISTURBANCES IN THE EASTERN SLOPES OF THE ROCKIES ${ }^{1}$
}

\author{
S.K. Takyi and R.M. Islam \\ Alberta Forest Service \\ Department of Energy and Natural Resources
}

Edmonton

\section{INTRODUCTION}

The Eastern Slopes of the Canadian Rocky Mountains include the alpine and subalpine ecoregions in Alberta. The area is characterized by cold winters, short cool summers and fewer than 60 frost-free days a year. These conditions result in a difficult task in the revegetation and rehabilitation of land disturbances by any reclamation standards.

Several abandoned, existing and planned strip coal mines are located in the Eastern Slopes, and some of the mines border the subalpine region. Land disturbances associated with other resource extraction activities are to be found extending into the alpine region.

${ }^{1} \mathrm{~A}$ paper presented at the Workshop on Revegetation Methods in the Mountains and Foothills. April 30 and May 1, 1984, Edmonton, Alberta, Canada. 
Natural regeneration on subalpine and alpine disturbances is a slow process because of the harsh physical environment of the ecoregions. The establishment of a protective plant cover with grasses and legumes is a primary technique to stabilize disturbed land surface and control erosion. The ability of plant species to adapt to a site is also an important requirement for successful revegetation. O.S. Aamodt ${ }^{1}$ wrote: "Nature did a superb job with the grasses and legumes, spreading them over much of the earth, adapting them to an immense range of climates. They would still be there to feed our flocks and herds and to hold and build the soil if there were no other crop plants whatever in the world." We recognize the importance of grasses when we review the status of reclamation in the alpine and subalpine regions of Alberta. The question which comes to mind is, where would we be without grasses and legumes in the reclamation of land disturbances in the mountains and foothills? This paper is about the adaptability of grasses and legumes; which species thrive best on land disturbances in Alberta's high elevation environments.

\section{BRIEF SITE DESCRIPTION AND METHODS}

Series of demonstration plots with various native grasses and cultivated grasses and legumes were established between 1975 and 1977 at different locations on land disturbances across the Eastern Slopes to aid in the choice of suitable species for the revegetation of land disturbances.

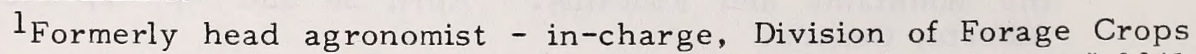
and Diseases, Bureau of Plant Industry. In: "Climate and Man, " 1941 Yearbook of Agriculture, U.S.D.A. 
In all the studies the choice of species and varieties was largely dictated by previous operational experiences gained in the area, and by the availability of seeds, especially of the native grasses. The locations of the demonstration planting and the adaptability trials are given in Figure 1 and Table 1. Nearly all of the sites are associated with coal mining. Several people have been involved in the studies discussed in this paper.

\section{A. Demonstration Plantings}

\section{Tent Mountain}

The study site is the Coleman Collieries Ltd. surface mine at Tent Mountain in the extreme southwestern corner of the province (Table 1). The site has a northern exposure with a $25^{\circ}$ slope and is at an elevation of $2133 \mathrm{~m}$ ASL. The disturbed overburden on which the planting was carried out is low in available nitrogen and phosphorus and is slightly acid in reaction. In the fall of 1975, 26 cultivated grasses and four legumes and three seed mixtures were planted on plots at the site. Seed was broadcast by hand at a rate of 10762 seeds $/ \mathrm{m}^{2}$ and fertilized by hand to provide $112 \mathrm{~kg} \mathrm{~N}, 67 \mathrm{~kg} \mathrm{P}$ and $34 \mathrm{~kg} \mathrm{~K} / \mathrm{ha}$.

2. Nine Locations in the Eastern Slopes (Adanac, Tent Mountain, Caw Creek Ridge, Luscar, Nordegg, Lovett Tower, Bighorn Dam, Racehorse Creek and Grassy Mountain)

During 1975 and 1976 several plantings of containerized native grass seedlings, in plots at different locations in the Eastern slopes 
FIGURE 1

\section{DEMONSTRATION PLANTINGS AND TRIAL LOCATIONS IN THE EASTERN SLOPES}

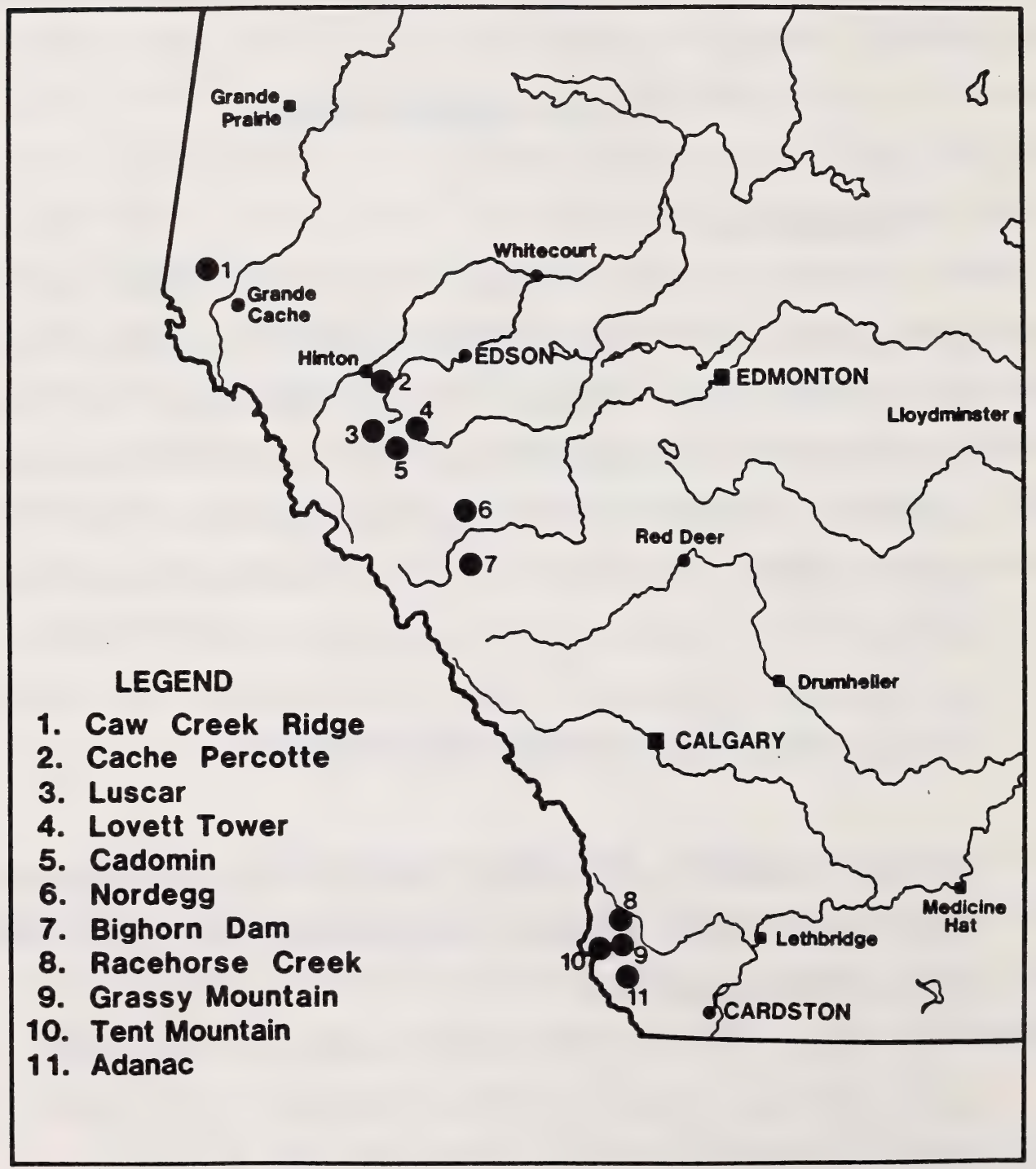


Table 1

LOCATIONS AND DISTURBANCE TYPES FOR THE DEMONSTRATION. PLANTINGS AND TRIALS IN THE EASTERN SLOPES

\begin{tabular}{|c|c|c|}
\hline Location & Ecoregion & $\begin{array}{c}\text { Disturbance } \\
\text { Type }\end{array}$ \\
\hline 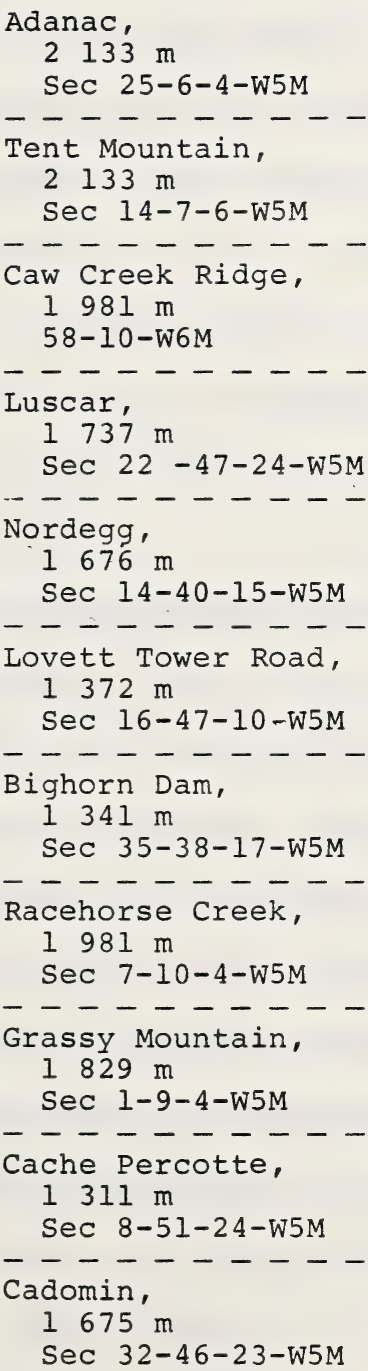 & $\begin{array}{l}\text { Subalpine } \\
\text { to Alpine } \\
\text { Subalpine } \\
\text { to Alpine } \\
\text { - - - - - } \\
\text { Subalpine } \\
\text { Subalpine } \\
\text { Sub - - - - - - - } \\
\text { Subalpine to } \\
\text { Boreal Upland } \\
\text { - - - - - - - } \\
\text { Subalpine to } \\
\text { Boreal Upland } \\
\text { - - - - - - - } \\
\text { Boreal Upland } \\
\text { - - - - - - - } \\
\text { Subalpine }\end{array}$ & 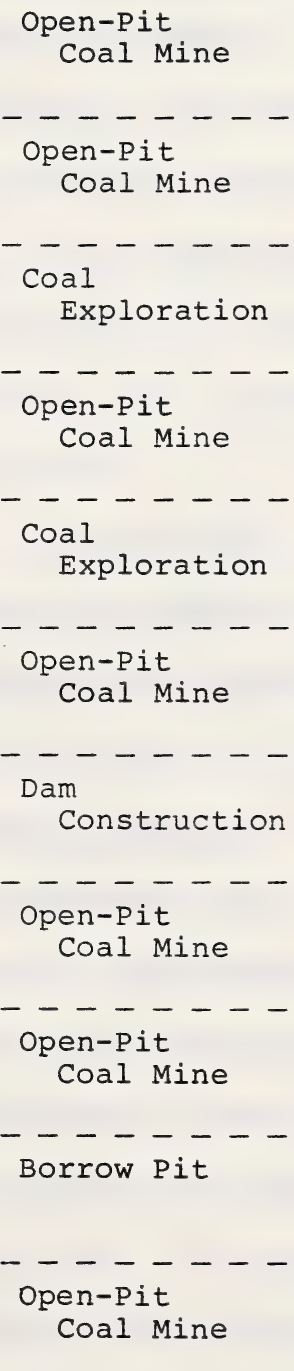 \\
\hline
\end{tabular}


(Table 1), were carried out with some assistance from the Genetics Department, University of Alberta. Seeds planted were collected from different altitudinal locations throughout the Eastern Slopes. In both years, the plantings were carried out in late July and early August.

\section{Cache Percotte}

The Cache Percotte planting site is a borrow pit at an elevation of $1311 \mathrm{~m}$; near Hinton (Table 1). It is a well-drained site. Fifteen-weekold containerized seedlings of 17 native grass species were planted in July, 1977 .

\section{B. Adaptability Trials}

\section{Tent Mountain}

This site is the same as described under the demonstration plantings and as shown in Table 1.

a. Cultivated Grasses and Legumes. In June 1977, two identical trials, one on disturbed overburden and the other on the overburden topdressed with 7.5 to $10 \mathrm{~cm}$ of a mineral soil, were established to evaluate the performance of 16 cultivated grasses and eight cultivated legumes on the site. The plots were laid out in a randomized complete block design with three replications. The seeding rate of each species provided 1,075 seeds $/ \mathrm{m}^{2}$. All legume seeds were inoculated at the time of seeding. The trials were not fertilized. 
b. Native Grasses. In September 1976, a set of trials was established on overburden to evaluate the performance of several native grasses and to compare them with two cultivated species. Tomm (1982) has described the methods of establishment and the experimental design.

\section{Cadomin}

The study site is an abandoned strip coal mine located in the westcentral part of the province near Cadomin (Table 1). The site and the properties of the spoil and overburden are described elsewhere in these proceedings by S.K. Takyi. In June of 1978, the trials were established on overburden topdressed with mineral soil to evaluate the performances of (i) nine cultivated grass and legume species, and a grass-legume mixture, and (ii) 13 native and two cultivated grasses.

a. Cultivated Grasses and Legumes. The trial was established on spoil topdressed with $20 \mathrm{~cm}$ of mineral soil. A randomized complete block design was used with four replications. Seed was applied by hand at a rate of $60 \mathrm{~kg} / \mathrm{ha}$. The grass plots were hand fertilized with 60-30-62 $\mathrm{kg} / \mathrm{ha}$ of $\mathrm{N}, \mathrm{P}$ and $\mathrm{K}$, respectively, and the legume plots with 20-30-62 $\mathrm{kg} / \mathrm{ha}$ of $\mathrm{N}, \mathrm{P}$ and $\mathrm{K}$, respectively, at the time of establishment of the trials. The legumes were inoculated with the appropriate inoculant prior to seeding. The plots received maintenance fertilization annually until the 1981 growing season. No fertilizers were applied in 1982 and 1983.

b. Native Grasses. The trial was established on overburden topdressed with $20 \mathrm{~cm}$ of the same mineral soil as was used in the cultivated species trial. A randomized complete block design with four replications was 
used. Each species was seeded to provide 5000 seeds per square metre. All plots were fertilized by hand to provide $71-50-65 \mathrm{~kg} / \mathrm{ha}$ of $\mathrm{N}, \mathrm{P}$ and $\mathrm{K}$, respectively. The plots received fertilizers annually at maintenance rates upto and including the 1981 growing season.

\section{RESULTS}

\section{Demonstration Plantings for Adaptability Evaluation}

\section{Cultivated Grasses and Legumes}

The species seeded in the fall of 1975 at Tent Mountain, except the legumes, had high germination rates in the first season. Most of the species, with the exception of the legumes, produced considerable levels of plant cover by the end of the first season (1976) of growth (Table 2). The poor plant cover in the legume plots was perhaps the result of winterkill of the germinants of the previous fall. Several of the plots were lost because of slope failure in 1977 and 1978. Plant cover improved in the grasses in 1977 but the legumes died out. As expected, plant cover in the grasses diminished in the third season (in the plots which were not affected by the slope failure) because there was no maintenance fertilization of the plots. Of the species remaining in 1978, the crested wheatgrasses, sheep fescue, Kentucky bluegrass and red top were the species which still provided adequate plant cover. The red top gave the highest dry matter yield among the species remaining in 1978 . 
Table 2

PERCENT PLANT COVER AND DRY MATTER PRODUCTION

OF CULTIVATED GRASSES AND LEGUMES SEEDED

AT TENT MOUNTAIN IN THE FALL OF 1975

\begin{tabular}{|c|c|c|c|c|}
\hline \multirow{2}{*}{ Species ${ }^{1}$} & \multicolumn{3}{|c|}{ Plant Cover, \& } & \multirow[t]{2}{*}{ Dry Matter, kg/ha } \\
\hline & 1976 & 1977 & 1978 & \\
\hline Thickspike wheatgrass & 25 & 20 & 16 & 1334 \\
\hline Crested wheatgrass - Nordan & 50 & 30 & 50 & 1252 \\
\hline Crested wheatgrass - Fairway & 40 & 50 & 28 & 1679 \\
\hline Sheep fescue & 40 & 65 & 32 & 658 \\
\hline Red fescue - Reptan & 25 & 20 & * & * \\
\hline Red fescue - Boreal & 20 & 60 & * & * \\
\hline Red fescue - Arctared & 40 & 33 & 25 & 1396 \\
\hline Timothy - Agmot & 20 & 40 & * & * \\
\hline Timothy & 20 & 20 & * & * \\
\hline Canada bluegrass & 50 & 44 & * & $\star$ \\
\hline Kentucky bluegrass - Mgget & 40 & 60 & * & * \\
\hline Kentucky bluegrass - Troy & 50 & 80 & 34 & 1125 \\
\hline Kentucky bluegrass - Draylan & 20 & 27 & * & * \\
\hline Meadow foxtail & 10 & 23 & 15 & 746 \\
\hline Meadow foxtail - Garrison & 50 & 27 & 15 & 412 \\
\hline Redtop & 95 & 50 & 35 & 3924 \\
\hline Redtop - Emerald & 50 & 83 & * & * \\
\hline Russian wild ryegrass & 25 & 38 & * & * \\
\hline Orchardgrass - Tardus & 50 & 42 & * & * \\
\hline Orchardgrass & 40 & 27 & 11 & 525 \\
\hline Bromegrass - Manchar & 30 & 59 & 22 & 803 \\
\hline Birdsfoot trefoil & 1 & 3 & * & * \\
\hline Cicer milkvetch & 1 & 0 & * & * \\
\hline Alfalfa - Rambler & 1 & 0 & * & $\star$ \\
\hline Alfalfa - Drylander & 1 & 0 & * & * \\
\hline
\end{tabular}

* Did not assess because of slope failure.

1 Western wheatgrass, slender wheatgrass, streambank wheatgrass hard sheep fescue and a Kentucky bluegrass were also planted. Plots for these five species were lost early because of slope failure. 


\section{Native Grass Species}

Tables 3 and 4 summarize the results of the native grass plantings in 1975 and 1976 at nine different locations along the Eastern Slopes for three selected years. The results indicate that the overall survival rates were high, especially during the early years after planting, and decreased somewhat with time. It could be speculated that frost heaving played a role in seedling mortality; the container seedlings had been planted in somewhat coarse materials. Other problems observed during assessments which contributed to mortality are water and wind erosion, excessive grazing, and damage caused by recreational vehicles. Generally it can be said that all the native grasses grew well and had high survival rates. Deschampsia caespitosa and Poa alpina among the species seeded in 1975 (Table 3) and Agropyron latiglume, Festuca saximontana, Koeleria cristata, Poa alpina and Poa interior among those seeded in 1976 (Table 4) had the highest percentage of survival in 1982 , the last year the plots were assessed. Flowering percentages of the surviving plants in these same species were among the best.

Tables 5 and 6 give the results of the native grass assessment in 1982 for five individual locations. In the southern third of the region (Adanac and Tent Mountain), Koeleria cristata, Poa interior, Poa alpina, Trisetum spicatum and Agropyron dasystachum had the highest percentage of survival. Agropyron latiglume grew very well and covered the entire plot in which it was planted. In the central part of the region (Bighorn Dam and Nordegg) several species had a high percentage of survival depending on the year of planting and location. Poa alpina, 


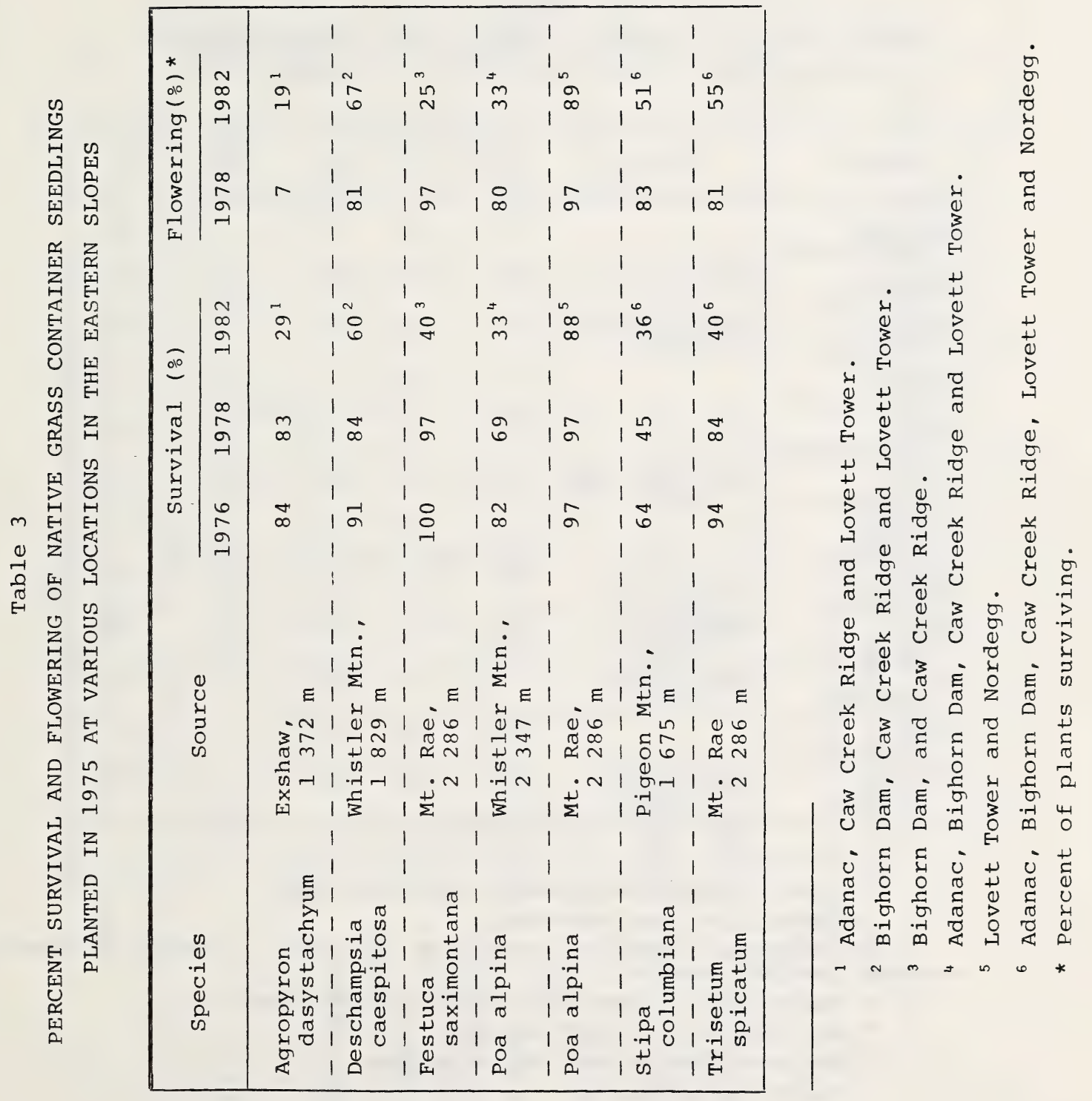


Table 4

PERCENT SURVIVAL AND FLOWERING OF NATIVE GRASS CONTAINER SEEDLINGS PLANTED IN 1976 AT VARIOUS LOCATIONS IN THE EASTERN SLOPES

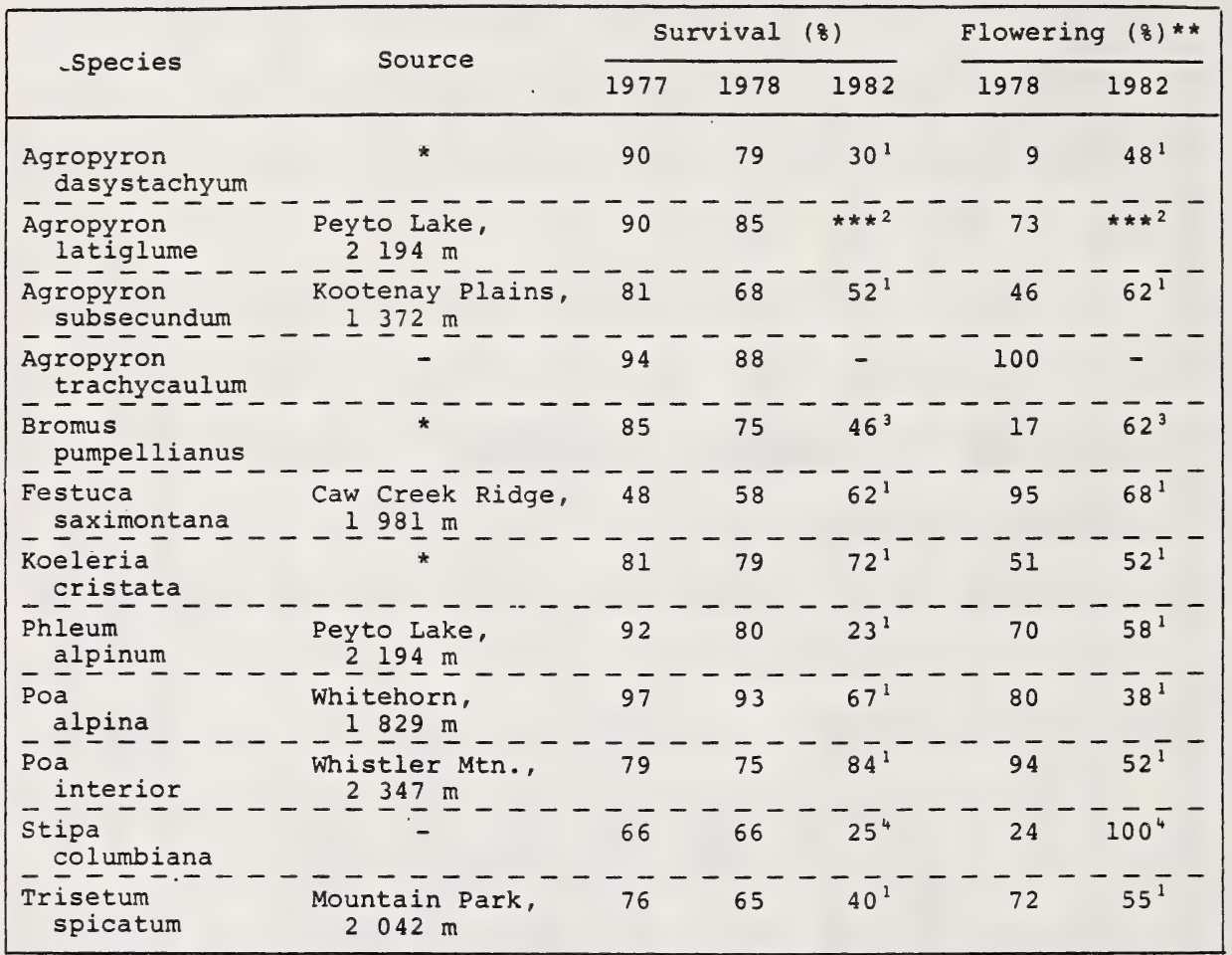

* Some hybridization therefore source irrelevant.

** Percent of plants surviving.

*** Overgrown - entire plot covered by the species. Difficult to identify individual seedlings planted.

1 Bighorn Dam, Caw Creek Ridge, Nordegg and Tent Mountain.

2 Caw Creek Ridge and Tent Mountain.

3 Caw Creek Ridge, Bighorn Dam and Nordegg.

4 Bighorn Dam and Nordegg. 


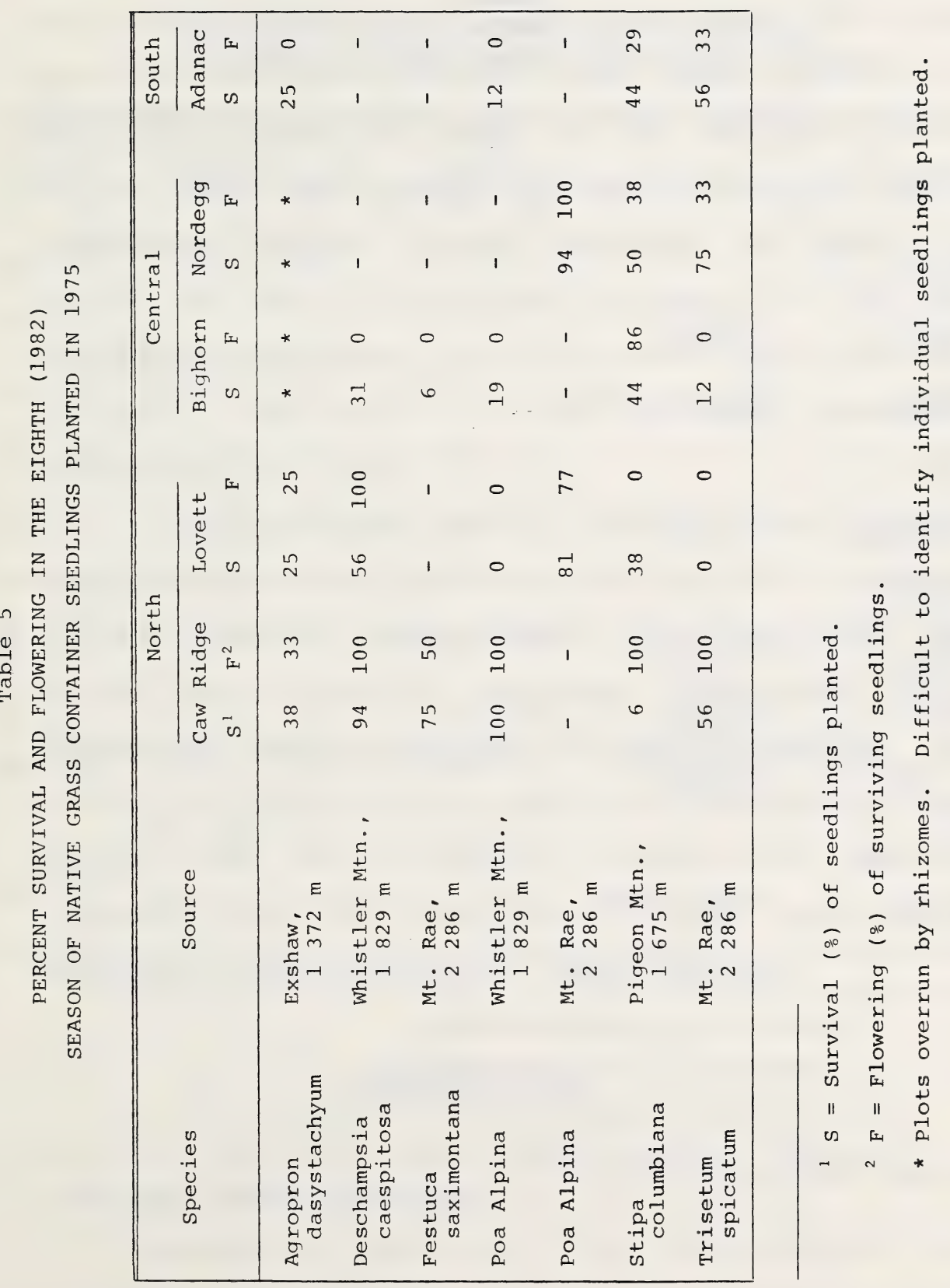


Table 6

PERCENT SURVIVAL AND FLOWERING IN THE SEVENTH (1982)

SEASON OF NATIVE GRASS CONTAINER SEEDLINGS PLANTED IN 1976

\begin{tabular}{|c|c|c|c|c|c|c|c|c|c|}
\hline \multirow{3}{*}{ Species } & \multirow{3}{*}{ Source } & \multicolumn{2}{|c|}{ North } & \multicolumn{4}{|c|}{ Central } & \multicolumn{2}{|c|}{ South } \\
\hline & & \multirow{2}{*}{$\begin{array}{l}\text { Caw } \\
\mathrm{S}^{1}\end{array}$} & \multirow{2}{*}{$\begin{array}{c}\text { Ridge } \\
F^{2}\end{array}$} & \multicolumn{2}{|c|}{ Nordegg } & \multicolumn{2}{|c|}{ Bighorn } & \multirow{2}{*}{$\begin{array}{c}\text { Tent } \\
\mathrm{s}\end{array}$} & \multirow{2}{*}{ Mtn. } \\
\hline & & & & $\mathrm{S}$ & $\mathbf{F}$ & $\mathrm{S}$ & $F$ & & \\
\hline $\begin{array}{l}\text { Agropyron } \\
\text { dasystachyum }\end{array}$ & * & 0 & 0 & 25 & 100 & 38 & 0 & 56 & 44 \\
\hline $\begin{array}{l}\text { Agropyron } \\
\text { latiglume }\end{array}$ & $\begin{array}{l}\text { Peyto Lake } \\
2194 \mathrm{~m}\end{array}$ & ** & $\star \star$ & - & - & - & - & $\star \star$ & * * \\
\hline $\begin{array}{l}\text { Agropyron } \\
\text { subsecundum }\end{array}$ & $\begin{array}{l}\text { Kootenay Plains } \\
\quad 1372 \mathrm{~m}\end{array}$ & 50 & 75 & 56 & 33 & 56 & 56 & 44 & 86 \\
\hline $\begin{array}{l}\text { Bromus } \\
\text { pumpellianus }\end{array}$ & * & 31 & 100 & $\star \star *$ & $\star \star$ & 56 & 11 & 50 & 75 \\
\hline $\begin{array}{l}\text { Festuca } \\
\text { saximontana }\end{array}$ & $\begin{array}{l}\text { Caw Creek Ridge } \\
1981 \mathrm{~m}\end{array}$ & 88 & 100 & 31 & 40 & 100 & 50 & 31 & 80 \\
\hline $\begin{array}{l}\text { Koeleria } \\
\text { cristata }\end{array}$ & * & 88 & 57 & 38 & 33 & 62 & 30 & 100 & 88 \\
\hline $\begin{array}{l}\text { Phleum } \\
\text { alpinum }\end{array}$ & $\begin{array}{l}\text { Peyto Lake } \\
2194 \mathrm{~m}\end{array}$ & 56 & 100 & 12 & 0 & 0 & 0 & 25 & 75 \\
\hline Poa alpina & $\begin{array}{l}\text { Whitehorn } \\
1829 \mathrm{~m}\end{array}$ & 81 & 100 & 94 & 13 & 0 & 0 & 94 & 0 \\
\hline Poa interior & $\begin{array}{l}\text { Whistler Mtn. } \\
\qquad 2347 \mathrm{~m}\end{array}$ & 100 & 100 & 56 & 0 & 81 & 8 & 100 & 100 \\
\hline $\begin{array}{l}\text { Stipa } \\
\text { columbiana }\end{array}$ & -- & - & - & 12 & 100 & 38 & 100 & - & - \\
\hline $\begin{array}{l}\text { Trisetum } \\
\text { spicatum }\end{array}$ & $\begin{array}{l}\text { Mountain Park } \\
2042 \mathrm{~m}\end{array}$ & 44 & 57 & 43 & 17 & 0 & 0 & 75 & 92 \\
\hline
\end{tabular}

$1 \mathrm{~S}=$ Survial $(\%)$ of seedlings planted.

$2 \mathrm{~F}=$ Flowering $(\xi)$ of surviving seedlings.

* Some hybridization therefore source irrelevant.

** Overgrown - entire plot covered by the species. Difficult to identify individual seedlings planted. 
$\underline{\text { Poa interior }}$ and Agropyron subsecundum are among those species with the highest survival percentages. Agropyron latiglume grew very well and covered the entire plot in which it was planted. In the northern part (Caw Creek Ridge and Lovett Tower), several species had a high percentage of survival depending on the year, seed source and location. At Caw Creek Ridge Agropyron latiglume, Poa interior, Poa alpina, Deschampsia caespitosa, Festuca saximontana and Koeleria cristata survived very well. At Lovett Tower, Poa alpina of Mt. Rae origin and Deschampsia caespitosa had the best survival. Table 7 summarizes this information. Performances of the individual species are described by Mihajlovich and Hall, 1982.

In the containerized planting in 1977 at Cache Percotte, a low elevation site near Hinton, percent survival of the plants remained high at the end of the sixth growing season in all but two species (Table 8 ). Survival was excellent in Agropyron subsecundum, Agropyron trachycaulum, Festuca saximontana and Agropyron latiglume. Flowering was poor in only four of the species, and in one species (Agropyron spicatum) there was no evidence of flowering in the sixth year at assessment time. The species showing the best vigor were Festuca saximontana, Festuca idohoensis and Elymus canadensis.

\section{Adaptability Trials}

\section{Cultivated Grasses and Legumes}

Percentage of plant cover in the fifth season in the trials established at Tent Mountain in 1977 are given in Table 9. In several of 
Table 7

NATIVE GRASS SPECIES WITH SOME POTENTIAL FOR RECLAMATION IN THE EASTERN SLOPES - BASED ON PERCENT SURVIVAL ON CONTAINERIZED SEEDLINGS (PLANTED IN 1975 AND 1976, AND ASSESSED IN 1982)

\begin{tabular}{|c|c|c|}
\hline North & Central & South \\
\hline $\begin{array}{l}\text { (Caw Ridge, } \\
\text { Lovett) }\end{array}$ & $\begin{array}{l}\text { (Bighorn Dam, } \\
\text { Nordegg) }\end{array}$ & $\begin{array}{l}\text { (Adanac, } \\
\text { Tent Mtn.) }\end{array}$ \\
\hline $\begin{array}{l}\text { Agropyron } \\
\text { latiglume } \\
\text { (C) * }\end{array}$ & $\begin{array}{l}\text { Agropyron } \\
\text { Dasystachyum }\end{array}$ & $\begin{array}{c}\text { Agropyron } \\
\text { latiglume } \\
\text { (T) }\end{array}$ \\
\hline $\begin{array}{l}\text { Poa interior } \\
\text { (C) }\end{array}$ & $\begin{array}{l}\text { Bromus } \\
\text { pumpellianus } \\
\text { (N) }\end{array}$ & $\begin{array}{l}\text { Koeleria } \\
\text { cristata } \\
\text { (T) }\end{array}$ \\
\hline Poa alpina & Poa interior & $\begin{array}{c}\text { Poa interior } \\
(\mathrm{T})\end{array}$ \\
\hline $\begin{array}{l}\text { Deschampsia } \\
\text { caespitosa }\end{array}$ & $\begin{array}{l}\text { Poa alpina } \\
(\mathrm{N})\end{array}$ & $\begin{array}{c}\text { Poa alpina } \\
(\mathrm{T})\end{array}$ \\
\hline $\begin{array}{l}\text { Festuca } \\
\text { saximontana } \\
\text { (C) }\end{array}$ & $\begin{array}{l}\text { Agropyron } \\
\text { subsecundum }\end{array}$ & $\begin{array}{l}\text { Trisetum } \\
\text { spicatum }\end{array}$ \\
\hline \multirow[t]{2}{*}{$\begin{array}{l}\text { Koeleria } \\
\text { cristata } \\
\text { (C) }\end{array}$} & $\begin{array}{l}\text { Koeleria } \\
\text { cristata } \\
\text { (B) }\end{array}$ & $\begin{array}{l}\text { Agropyron } \\
\text { dasystachum } \\
(\mathrm{T})\end{array}$ \\
\hline & $\begin{array}{l}\text { Trisetum } \\
\text { spicatum } \\
\text { (N) }\end{array}$ & $\begin{array}{l}\text { Stipa } \\
\text { columbiana } \\
\text { (A) }\end{array}$ \\
\hline
\end{tabular}

$$
\begin{array}{rlrl}
{ }^{*} \mathrm{~A} & =\text { Adanac } & \mathrm{B} & =\text { Bighorn Dam; } \\
\mathrm{C} & =\text { Caw Creek Ridge; } & \mathrm{N}=\text { Nordegg; } \\
\mathrm{T} & =\text { Tent Mountain. } & &
\end{array}
$$

No letter after a species indicates survival was high at each location under the column it appears. 
Table 8

PERCENT SURVIVAL AND FLOWERING OF CONTAINERIZED

NATIVE GRASS SEEDLINGS IN 1982 OF THE 1977

PLANTINGS AT CACHE PERCOTTE

\begin{tabular}{|lcc|}
\hline \multicolumn{1}{|c}{ Species } & Survival $(\mathrm{z})$ & Flowering $^{1}$ \\
\hline Agropyron albicans & 45.4 & 3 \\
Agropyron dasystachyum & 41.7 & 13 \\
Agropyron latiglume & 85.6 & 49 \\
Agropyron smithii & 33.5 & 9 \\
Agropyron spicatum & 61.9 & 0 \\
Agropyron subsecundum & 99.7 & 35 \\
Agropyron trachycaulum & 92.7 & 89 \\
Agropyron sp. & 30.3 & 52 \\
Elymus canadensis & 75.5 & 95 \\
Festuca idahoensis & 72.1 & 54 \\
Festuca saximontana & 96.9 & 90 \\
Koeleria cristata & 17.1 & 71 \\
Phleum alpinum & 60.0 & 69 \\
Poa alpina & 75.8 & 76 \\
Poa cusickii & 50.0 & 33 \\
Poa interior & 16.7 & 40 \\
Trisetum spicatum & 29.6 & 89 \\
& & \\
\hline
\end{tabular}

1 Flowering ( $\%$ ) of surviving seedlings. 
Table 9

PERCENT PLANT COVER IN THE FIFTH SEASON (1981)

AFTER SEEDING CULTIVATED GRASSES AND LEGUMES

AT TENT MOUNTAIN

\begin{tabular}{|c|c|c|}
\hline Species & $\begin{array}{c}\text { Raw } \\
\text { Overburden }\end{array}$ & $\begin{array}{l}\text { Topdressed } \\
\text { Overburden }\end{array}$ \\
\hline Creeping red fescue & $45 \mathrm{~b}$ & 43 a \\
\hline Meadow fescue & 24 defg & 18 bcdef \\
\hline Chewing fescue & 70 a & $32 a b$ \\
\hline Artic fescue & $41 \mathrm{bc}$ & $26 \mathrm{abcd}$ \\
\hline Tall fescue & 12 ghij & 18 bcdef \\
\hline Pubescent wheatgrass & 22 defgh & 12 bcdef \\
\hline Slender wheatgrass & 18 efghi & 12 bcdef \\
\hline Crested wheatgrass & 19 efgh & 5 ef \\
\hline Kentucky bluegrass & 31 bcdef & $27 \mathrm{abc}$ \\
\hline Canada bluegrass & $38 \mathrm{bcd}$ & 24 abcde \\
\hline Upland bluegrass & 31 bcdef & 10 cdef \\
\hline Smooth bromegrass & 34 bcde & 10 cdef \\
\hline Climax timothy & 23 defgh & 21 bcdef \\
\hline Redtop & 15 fghij & $27 \mathrm{abcd}$ \\
\hline Highland bentgrass & $12 \mathrm{ghij}$ & 13 bcdef \\
\hline Russian wild rye & 25 cdefg & $2 \mathrm{f}$ \\
\hline 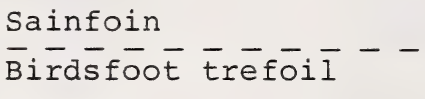 & $-\frac{10}{1} \frac{g h i j}{j}-$ & $-\frac{4}{6} \frac{\mathrm{ef}}{\mathrm{de}} \overline{\mathrm{f}}-$ \\
\hline Alfalfa & 24 defg & $29 \mathrm{abc}$ \\
\hline White clover & $1 \mathrm{j}$ & 14 bcdef \\
\hline Red clover & $6 \mathrm{hij}$ & 14 bcdef \\
\hline Alsike clover & $2 i j$ & 27 abcd \\
\hline Sweet clover (white) & $1 \mathrm{j}$ & $1 \mathrm{f}$ \\
\hline Sweet clover (yellow) & $2 i j$ & $2 \mathrm{f}$ \\
\hline
\end{tabular}

Means in a column followed by the same letter are not significantly different at the $5 \%$ level (Duncan's Multiple Range Test). 
the species, cover had declined from the levels measured before 1981 . On the topdressed overburden, creeping red, chewing and arctic fescues, Kentucky and Canada bluegrasses, and red top still provided adequate cover. On the raw overburden, however, upland bluegrass and smooth bromegrass as well as those species listed for topdressed overburden produced adequate plant cover. Among the legumes, alfalfa was the best species on both raw overburden and topdressed overburden. With topdressing, however, white, red and alsike clover improved considerably over the plant cover on the raw overburden.

The results of the trials established at Cadomin in 1978 on topdressed spoil with nine cultivated grasses and legumes are summarized in Tables 10 and 11. Up to the end of the fourth season of growth (1981) when maintenance fertilization was carried out, all of the species, produced adequate plant cover. The same general observation was true for plant vigor and seedhead production. The sweet clover, a biennial, had reseeded by itself and therefore produced good plant stands in the fourth season. With no fertilization of the plots in 1982, percentage of plant cover and vigor decreased considerably in all species except alfalfa. Although there was an overall lowering of seedhead production in most species with the withdrawal of fertilizer in 1982, the changes were, in most cases, small.

Biomass production at the fourth growing season (plots fertilized annually) was generally high in all but the Kentucky bluegrasses. Legume production was high; including the alsike clover which had essentially disappeared in other trials at the site when it was seeded in a mixture with other cultivated grasses. The reduction in plant cover and 
Table 10

PLANT COVER (PERCENT) AND DRY MATTER PRODUCTION $\left(\mathrm{g} / 0.25 \mathrm{~m}^{2}\right)$ OF CULTIVATED GRASSES AND LEGUMES ON SPOIL TOPDRESSED WITH MINERAL SOIL AT CADOMIN

\begin{tabular}{|c|c|c|c|}
\hline \multirow{2}{*}{ Species } & \multicolumn{2}{|c|}{ Plant Cover } & \multirow{2}{*}{$\frac{\text { Dry Matter }}{1981}$} \\
\hline & 1981 & $1982^{1}$ & \\
\hline $\begin{array}{l}\text { Kentucky bluegrass - } \\
\text { nugget }\end{array}$ & $68.8 \mathrm{a}$ & $35.0 \mathrm{e}$ & $19.3 \mathrm{a}$ \\
\hline $\begin{array}{l}\text { Kentucky bluegrass - } \\
\text { park }\end{array}$ & $87.2 \mathrm{bcde}$ & $59.8 \mathrm{abc}$ & $44.3 \mathrm{ab}$ \\
\hline Bromegrass & $98.0 \mathrm{e}$ & $64.5 \mathrm{bc}$ & $145.1 \mathrm{de}$ \\
\hline Creeping red fescue & $93.5 \mathrm{de}$ & $73.1 \mathrm{ab}$ & $66.7 \mathrm{abc}$ \\
\hline Crested wheatgrass & $81.8 \mathrm{abcd}$ & $39.6 \mathrm{e}$ & $110.8 \mathrm{cde}$ \\
\hline Timothy & $91.3 \mathrm{cde}$ & $50.7 \mathrm{cde}$ & $83.7 \mathrm{bcd}$ \\
\hline Alsike clover & $91.3 \mathrm{cde}$ & $4.0 \mathrm{f}$ & $124.8 \mathrm{cde}$ \\
\hline Alfalfa & $99.2 \mathrm{e}$ & 83.0 a & $171.0 \mathrm{e}$ \\
\hline Sweet clover & $76.0 \mathrm{ab}$ & $4.3 \mathrm{f}$ & $138.3 \mathrm{de}$ \\
\hline $\begin{array}{l}\text { Species mix } \\
\text { (all above) }\end{array}$ & $99.0 \mathrm{e}$ & 89.4 a & $159.3 \mathrm{e}$ \\
\hline
\end{tabular}

1 No fertilizers applied in 1982.

Means followed by a common letter in a column in a given year are not significantly different at the 5\% level (Duncan's Multiple Range Test). 
Table 11

PLANT VIGOR* AND SEED HEAD PRODUCTION* OF CULTIVATED GRASSES AND LEGUMES ON SPOIL TOPDRESSED WITH MINERAL SOIL AT CADOMIN

\begin{tabular}{|c|c|c|c|c|}
\hline \multirow{2}{*}{ Species } & \multicolumn{2}{|c|}{ Plant Vigor } & \multicolumn{2}{|c|}{ Seed Head } \\
\hline & 1981 & $1982^{1}$ & 1981 & $1982^{1}$ \\
\hline $\begin{array}{l}\text { Kentucky bluegrass - } \\
\text { nugget }\end{array}$ & $5.5 \mathrm{ab}$ & 3.0 cde & $4.5 a$ & 4.2 abcde \\
\hline $\begin{array}{l}\text { Kentucky bluegrass - } \\
\text { park }\end{array}$ & $5.5 a b$ & $2.0 \mathrm{e}$ & $5.0 \mathrm{ab}$ & $1.2 \mathrm{~g}$ \\
\hline Bromegrass & $6.5 \mathrm{bc}$ & $6.0 \mathrm{ab}$ & $6.3 \mathrm{~cd}$ & $4.7 \mathrm{abc}$ \\
\hline Creeping red fescue & $6.5 \mathrm{bc}$ & $5.0 \mathrm{abc}$ & $6.3 \mathrm{~cd}$ & 3.5 abcdef \\
\hline Crested wheatgrass & $5.5 \mathrm{ab}$ & 3.2 cde & $5.5 \mathrm{abc}$ & $4.5 \mathrm{abcd}$ \\
\hline Timothy & $5.0 \mathrm{a}$ & 3.0 cde & $6.0 \mathrm{abc}$ & 4.2 abcde \\
\hline Alsike clover & $7.0 \mathrm{c}$ & $2.7 \mathrm{de}$ & $7.0 \mathrm{~d}$ & 2.5 cdefg \\
\hline Alfalfa & $7.0 \mathrm{c}$ & $6.2 \mathrm{ab}$ & $7.0 \mathrm{~d}$ & $5.2 \mathrm{ab}$ \\
\hline Sweet clover & $7.0 \mathrm{c}$ & $4.5 \mathrm{abcd}$ & $7.0 \mathrm{~d}$ & 1.7 bcdef \\
\hline $\begin{array}{l}\text { Species mix } \\
\text { (all above) }\end{array}$ & $7.0 \mathrm{c}$ & $6.2 \mathrm{a}$ & $7.0 \mathrm{~d}$ & $5.5 \mathrm{a}$ \\
\hline
\end{tabular}

7 (excellent).

* Subjective rating based on a scale of 1 (poor) to

1 No fertilizers applied in 1982.

Means in a column followed by a common letter are not significantly different at the 58 level. (Duncan's Multiple Range Test). 
biomass production of the grass species which occurred in the fifth year (1982) are due to nitrogen deficiency and a low level of available phosphorus following discontinuation of maintenance fertilization in that year. Chlorosis and mortality in the grasses were common. Alfalfa and the species mix (containing alfalfa) maintained the best dry matter yields, vigor and seedhead production even after stoppage of annual maintenance fertilization, apparently due to the nitrogen-fixing ability of alfalfa. Alfalfa should be considered a good legume in seed mixtures for operational reclamation in similar environments.

\section{Native Grasses}

Plant cover levels in 1981 for several native grasses of different seed sources seeded at Tent Mountain in September, 1976, are given in Table 12. Plant cover was poor for most species, including the cultivated species used in the trials for comparison. Generally, plant cover for all of the species increased and peaked in 1979 (three seasons) and by 1981 had started to decline in all but two of the species; Festuca rubra and Poa interior. The best species after five seasons, in terms of cover production, were the three native Festucas (rubra, saximontana and

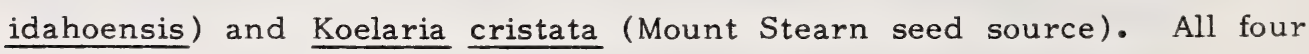
species gave higher plant cover than the cultivated species used for comparison. Stipa comata from the Kootenay Plains had died out by the third year and it did not regenerate in 1980 or 1981. Differences in cover between four of the five Agropyron subsecundums of different seed sources were small. The Region Mountain seed source produced the best cover among the five Agropyron seed sources. Koelaria cristata of 
Table 12

PERCENT PLANT COVER IN NATIVE GRASS SPECIES

PLANTED AT TENT MOUNTAIN IN SEPTEMBER, 1976

\begin{tabular}{|c|c|c|c|c|}
\hline Species & Source & 1977 & 1979 & 1981 \\
\hline $\begin{array}{l}\text { Agropyron } \\
\text { subsecundum }\end{array}$ & $\begin{array}{l}\text { Athabasca Ranch, } \\
1018 \mathrm{~m}\end{array}$ & 16 & 31 & 14 \\
\hline $\begin{array}{l}\text { Agropyron } \\
\text { subsecundum }\end{array}$ & $\begin{array}{c}\text { Bragg Creek, } \\
\text { I } 829 \mathrm{~m}\end{array}$ & 9 & 16 & 13 \\
\hline $\begin{array}{l}\text { Agropyron } \\
\text { subsecundum }\end{array}$ & $\begin{array}{l}\text { Grotto Mtn.. } \\
1433 \mathrm{~m}\end{array}$ & 12 & 34 & 15 \\
\hline $\begin{array}{l}\text { Agropyron } \\
\text { subsecundum }\end{array}$ & $\begin{array}{l}\text { Kootenay Plains, } \\
\quad 1372 \mathrm{~m}\end{array}$ & 14 & 35 & 12 \\
\hline $\begin{array}{l}\text { Agropyron } \\
\text { subsecundum }\end{array}$ & $\begin{array}{l}\text { Pigeon Mtn., } \\
\text { I } 524 \mathrm{~m}\end{array}$ & 13 & 31 & 21 \\
\hline $\begin{array}{l}\text { Agropyron } \\
\text { trachycaulum }\end{array}$ & $\begin{array}{l}\text { Gibraltar Mtn., } \\
1829 \mathrm{~m}\end{array}$ & 7 & 26 & 20 \\
\hline $\begin{array}{l}\text { Agropyron } \\
\text { trachycaulum }\end{array}$ & $\begin{array}{l}\text { Waterton, } \\
1372 \mathrm{~m}\end{array}$ & 8 & 22 & 17 \\
\hline Agrostis scabra & $\begin{array}{l}\text { Gibraltar Mtn., } \\
1829 \mathrm{~m}\end{array}$ & 11 & 32 & 8 \\
\hline $\begin{array}{l}\text { Festuca } \\
\text { idahoensis }\end{array}$ & $\begin{array}{c}\text { Windsor Ridge, } \\
1737 \mathrm{~m}\end{array}$ & 14 & 38 & 40 \\
\hline Festuca rubra & $\begin{array}{c}\text { Rampart Creek, } \\
1448 \mathrm{~m}\end{array}$ & 22 & 58 & 75 \\
\hline $\begin{array}{l}\text { Festuca } \\
\quad \text { saximontana }\end{array}$ & Mt. Rae, $2286 \mathrm{~m}$ & 18 & 44 & 37 \\
\hline $\begin{array}{l}\text { Koeleria } \\
\text { cristata }\end{array}$ & $\begin{array}{c}\text { Grotto Mt., } \\
1433 \mathrm{~m}\end{array}$ & 13 & 29 & 22 \\
\hline $\begin{array}{l}\text { Koeleria } \\
\quad \text { cristata }\end{array}$ & $\begin{array}{l}\text { Mt. Stearn, } \\
\text { I } 646 \mathrm{~m}\end{array}$ & 19 & 46 & 33 \\
\hline Phleum alpinum & $\begin{array}{l}\text { Cut creek, } \\
1585 \mathrm{~m}\end{array}$ & 6 & 14 & 13 \\
\hline Poa interior & $\begin{array}{l}\text { Whistler Mtn., } \\
2337 \mathrm{~m}\end{array}$ & 8 & 11 & 19 \\
\hline Stipa comata & $\begin{array}{l}\text { Kootenay Plains, } \\
\quad 1372 \mathrm{~m}\end{array}$ & 2 & 0 & 0 \\
\hline $\begin{array}{l}\text { Trisetum } \\
\text { spicatum }\end{array}$ & $\begin{array}{l}\text { Whitehorn Mtn., } \\
2012 \mathrm{~m}\end{array}$ & 22 & 28 & 20 \\
\hline $\begin{array}{l}\text { Agropyron } \\
\text { trachycaulum } \\
\text { 'Revenue' }\end{array}$ & -- & 18 & 43 & 24 \\
\hline $\begin{array}{l}\text { Calamagrostis } \\
\text { purpurascens } \\
\text { var. commutata*1 }\end{array}$ & $\begin{array}{l}\text { Nihahi Ridge, } \\
\quad 1829 \mathrm{~m}\end{array}$ & 8 & 10 & 17 \\
\hline
\end{tabular}

* Unknown cultivar.

1 Cultivated species 
Mt. Stearn seed source produced 50\% more cover than the Grotto Mountain seed source. Continued high plant cover production with no maintenance fertilization (plots fertilized at time of seeding) for the Festuca rubra of Rampart Creek seed source, up to five seasons after seeding, indicates the good potential of this species collected at that location for reclamation in the region.

The native grass species adaptability trial started at Cadomin in 1978 showed considerable differences in percentage of plant cover between species after four seasons of growth (Table 13). Between seeding and the fourth season, the plots were fertilized annually in June. During this period, cover increased progressively in all but one species. In every species, cover in 1981 was the highest it had ever been. The three native Agropyrons (dasystachum, subsecundum and trachycaulum), the Deschampsia caespitosa and the native Festuca (rubra and saximontana) along with the two cultivated species (Agropyron trachycau-

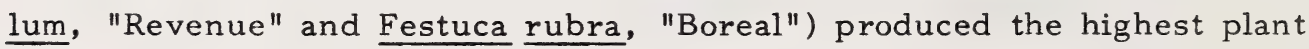
cover. All of the plots grew well and rated good in plant vigor up to and including 1981 since they were fertilized annually. None of the plots were fertilized in 1982 or 1983. Observations in 1982 and 1983 indicated that both productivity and plant vigor had started to decline; the change being particularly apparent in 1983.

\section{CONCLUSIONS}

The demonstration plantings of native and cultivated grass species and legume species across the foothills on land disturbances, and the 
Table 13

PERCENT PLANT COVER AND PLANT VIGOR* OF NATIVE GRASS

SPECIES ON OVERBURDEN TOPDRESSED WITH MINERAL SOIL

AT CADOMIN (TPIAL ESTABLISHED IN 1978)

\begin{tabular}{|c|c|c|c|}
\hline \multirow{2}{*}{ Species } & \multicolumn{2}{|c|}{ Plant Cover } & \multirow{2}{*}{$\frac{\text { Plant Vigor }}{1981}$} \\
\hline & 1979 & 1981 & \\
\hline Agropyron dasystachyum & $26.1 \mathrm{e}$ & 57 ef & $4.5 \mathrm{abc}$ \\
\hline Agropyron subsecundum & $20.9 \mathrm{de}$ & 42 abcde & $3.8 \mathrm{a}$ \\
\hline Agropyron trachycaulum & $20.5 \mathrm{de}$ & 48 bcdef & $4.5 \mathrm{abc}$ \\
\hline Calamagrostis purpurascens & $4.1 \mathrm{ab}$ & $31 \mathrm{ab}$ & $5.5 \mathrm{c}$ \\
\hline Deschampsia caespitosa & $10.0 \mathrm{bc}$ & 44 abcdef & $5.8 \mathrm{c}$ \\
\hline Festuca idahoensis & $2.6 a b$ & 31 a & $5.5 \mathrm{c}$ \\
\hline Festuca saximontana & $4.1 \mathrm{ab}$ & 41 abcde & $4.8 \mathrm{abc}$ \\
\hline Festuca rubra & $14.5 \mathrm{~cd}$ & 46 bcdef & $4.8 \mathrm{abc}$ \\
\hline Koelaria cristata & $4.1 \mathrm{ab}$ & 38 abcde & $5.3 \mathrm{bc}$ \\
\hline Phleum alpinum & $8.1 \mathrm{abc}$ & $35 \mathrm{abc}$ & $4.0 \mathrm{ab}$ \\
\hline Poa interior & $3.0 \mathrm{ab}$ & $30 a$ & $4.3 \mathrm{abc}$ \\
\hline Stipa columbiana & 0.6 a & $30 a$ & $4.5 \mathrm{abc}$ \\
\hline Trisetum spicatum & $7.2 \mathrm{abc}$ & $36 \mathrm{abc}$ & $4.0 \mathrm{ab}$ \\
\hline$--------\cdots$ & $-\cdots-$ & ----- & $--\cdots$ \\
\hline $\begin{array}{l}\text { Agropyron trachycaulum } \\
\text { 'Revenue' }\end{array}$ & $15.0 \mathrm{~cd}$ & 51 cdef & $4.8 \mathrm{abc}$ \\
\hline Festuca rubra 'Boreal' & $21.2 \mathrm{de}$ & $60 \mathrm{f}$ & $5.8 \mathrm{c}$ \\
\hline
\end{tabular}

* Subjective rating based on a scale of 1 (poor) to 7 (excellent).

1 Cultivated species.

Means in a column followed by the same letter are not significantly different at the 5\% level. (Duncan's Multiple Range Test). 
adaptability trials on abandoned surface mine disturbances in the same region, have provided the following information:

1. In terms of plant cover and biomass production, the cultivated grasses have performed well for the duration of the studies (up to seven seasons). In the southern part of the region (Tent Mountain), the fescues, bluegrasses, crested wheatgrass and red top grew well. In the northern part (Cadomin) all six cultivated grasses grew well.

2. Alfalfa, among the relatively-few legumes planted, performed best and should be seriously considered in the seed mixtures used in the sub-alpine region. It was observed to have done very well when grown alone, and to have improved plant cover in plots where it was a component of the seed mix.

3. The native grasses persisted and provided adequate plant cover in some instances, but they were generally slower than the cultivated grasses in developing adequate plant cover. There were distinct differences among the species. Generally, the Agropyrons, the Festucas and the Poas appear to persist well across the region in most of the plantings. There were, however, definite differences among species on disturbances at given locations. The choice of a species for ground cover establishment should be dictated primarily by the location and the severity of the site.

4. Our operational experience in the high alpine region shows that cultivated grasses grow well and have persisted longer than eight years without dying out. The information summarized in 
this paper suggests that most of the cultivated grasses will grow and perform fairly well on disturbances in the region. The choice of a species for particular reclamation conditions should be dictated primarily by the regional conditions and the microsite conditions. 



\section{REFERENCES}

King, P. 1980. Tent Mountain Demonstration Plantings - 1979. Alberta Department of Energy and Natural Resources, Alberta Forest Service, Edmonton.

Mihajlovich, M.M. and Hall, L. 1982. Reclamation Experiments in the Eastern Slopes of Alberta. Final Report prepared for the Reclamation Research Technical Advisory Committee. RRTAC Project 82-12-Tom. Alberta Department of Energy and Natural Resources, Alberta Forest Service, Edmonton.

Mihajlovich, M.M. and Russell, W.B. 1980. Tent Mountain Reclamation Demonstration Plantings, 1977 and 1978. Alberta Department of Energy and Natural Resources, Alberta Forest Service, Edmonton.

Russell, W.B. and Takyi, S.K. 1979. The Cadomin Reclamation Research Project. First year results (1978). Alberta Department of Energy and Natural Resources, Alberta Forest Service, Edmonton.

Selner, J. 1973. Surface Mine Reclamation Research in Alberta. Progress Report. Alberta Department of Lands and Forests, Alberta Forest Service, Edmonton.

Selner, J. and King, P. 1977. Native Grass Study. Species Adaptability Trials. ENR Report No. 18. Alberta Department of Energy and Natural Resources, Alberta Forest Service, Edmonton.

Selner, J., King, P. and Hildebrandt, D. 1977. Progress Report for Tent Mountain Coal-mined Land. Reclamation Trials (1975-76). Alberta Department of Energy and Natural Resources, Alberta Forest Service, Edmonton.

Takyi, S.K. 1984. Role of Topsoil, Fertilizers and Companion Crops in Revegetation of Two Severe Sites in the Alberta Foothills and Mountains. ENR Report No. T/67. Alberta Department of Energy and Natural Resources, Alberta Forest Service, Edmonton. 
1984. Plant Cover Establishment Methods on a Severe Rocky Mountain Foothills Site. ENR Report No. T/66. Alberta Department of Energy and Natural Resources, Alberta Forest Service, Edmonton.

Takyi, S.K. and Russell, W.B. 1980. The Cadomin Reclamation Research Project. Second Year Results (1979). Alberta Department of Energy and Natural Resources, Alberta Forest Service, Edmonton.

Tomm, H. 1982. Progress Report on the Tent Mountain Grass and Legume Reclamation Trials. Alberta Department of Energy and Natural Resources, Alberta Forest Service, Edmonton. 

